\title{
Distance foreign language learning The experience of Anadolu University
}

\author{
Dilek Altunay — M. Emin Mutlu \\ Anadolu University \\ Open Education Faculty \\ 26470 Eski ehir TURKEY \\ \{daltunay,memutlu\}@anadolu.edu.tr
}

\begin{abstract}
This study will present an Internet-based distance language learning model at Anadolu University and will try to find out students' views about distance language learning. Firstly, the positive and negative aspects of using ICT in distance language learning will be mentioned briefly. Then, Turkish Language Certificate Programme (TSP), which can be a model for the development of online courses for different languages, will be introduced. Students' examination results were obtained to see whether the programme helps foreign language learning and an electronic interview was conducted with a group of students to know students' ideas about the programme and distance language learning in general. It can be concluded that distance education helps language learning. Students think that distance education is a good opportunity for foreign language learning, but they do not see it as being as efficient as language learning abroad or in traditional classrooms.

RÉSUMÉ. Cet article présente un modèle d'apprentissage des langues à distance par Internet à l'Université Anadolu et les avis des étudiants du programme à propos de l'apprentissage des langues à distance. Dans un premier temps, les aspects positifs et négatifs sur l'utilisation des TIC dans l'apprentissage des langues à distance sont mentionnés brièvement. Puis, le programme de certificat de la langue turque (TSP), qui peut être un modèle pour le développement des cours en ligne pour des langues différentes, est présenté. Les résultats d'examen des étudiants ont été recueillis pour voir si le programme aide l'apprentissage des langues étrangères et un entretien électronique a été conduit avec un groupe d'étudiants pour avoir leur avis sur le programme et l'apprentissage des langues à distance en général. On peut conclure que la formation à distance aide l'apprentissage des langues. Les étudiants pensent que la formation à distance est une bonne occasion pour l'apprentissage des langues étrangères, mais ils ne le voient pas aussi efficace que l'apprentissage des langues à l'étranger ou dans des classes traditionnelles.

KEYWORDS: distance language learning, information and communication technologies (ICT), computer mediated communication (CMC).

MOTS-CLÉS : apprentissage des langues à distance, Technologies de l'information et de la communication (TIC), communication médiatisée par ordinateur (CMO).
\end{abstract}

DOI:10.3166/DS.8.463-473 @ Cned/Lavoisier 2010

D\&S - 8/2010. Enseignement des langues, pages 463 to 473 


\section{Introduction}

Distance education offers advantages to people who would like to receive education but who cannot do it for different reasons. It also removes physical barriers among learners and tutors and gives learners the chance to study whenever and wherever they want. Today, thanks to developments in Information and Communication Technologies (ICT), many technological tools have been used in distance education. As for language learning through distance education, distance education can be a good support for those who cannot go to language courses/schools due to reasons such as lack of time or cost. There are various views and studies that support the benefits of language learning through distance education, particularly the use of ICT in distance language learning. For instance, use of computers can be considered as ideal for carrying out repetitive exercises and for providing immediate feedback, and the Internet allows learners to interact synchronously or asynchronously with other learners and the speakers of the target language at any time (Warschauer, 1996).

Technology offers various opportunities to apply language teaching principles. For example, textual enhancement, which is a kind of input enhancement by changing text appearance through highlighting, font changes, animations, or other special effects in order to direct learners' attention to non-salient forms, is possible thanks to technology. Pop-up windows that provide lexical assistance or very brief explanations of material that are not understood by learners, and input flooding can also be created easily (Doughty 1991, 1992). Various Internet-based resources which include the target forms and which can be appropriate for the learners' level can be used to provide rich input. They provide opportunities for exposure to authentic language input and make language learning fun since they include pictures, interactive forms, animation, colour, sound, and digital video clips (Gitsaki and Taylor, 1999). In addition, synchronous and asynchronous facilitation services (tutoring) provide opportunity for interaction and collaborative learning. Also, visual saliency of linguistics forms during text-chat may help learners to either confirm or disconfirm their hypotheses about the target language (Chapelle, 2001).

When tutor support, input and interaction are not available in distance learning context and when learners cannot meet technical requirements, language learning process may be hindered. Gillespie and McKee (1999) found that learners resist using ICT in distance language learning because learners may have problems regarding to access, equipment and compatibility. Learners may face administrative problems and problems regarding the management of e-mail numbers and accounts. Use of faulty disks, forgetting to make backups can lead to loss of work and panic. Distance language learners may also have problems with carrying speaking activities with their peers or facilitators. Speech recognition technology is available today to improve pronunciation, but it is not used in most of the programmes yet. 


\section{Turkish language certificate programme (TSP)}

Turkish language certificate programme (TSP) has been offered by Anadolu University, Open Education Faculty since 2007. The target learners of the Turkish Language Certificate programme is the $3^{\text {rd }}$ or $4^{\text {th }}$ generation Turkish people residing in Europe and who think they are not able to communicate effectively in Turkish, and also foreigners who would like to learn Turkish. Many efforts were put while preparing the programme to make Turkish language learning easy for the learners.

Before starting the implementation of the programme, a pilot study was carried out by a group of Anadolu University staff. During the pilot study, the facilitators were given training on how to offer synchronous facilitation services online. The first pilot study was carried out with a group of Erasmus students and feedback was received from the students. After identifying the problems that the learners faced in the pilot, the things that should be done to prevent potential problems have been stated in the instructions and examination guides. The web site has been prepared in 4 languages i.e. Turkish, English, French, and German. In addition, a help desk in the Computer Aided Instruction Centre offers help in technical and student affairs by e-mail and telephone in these 4 languages.

In TSP, language skills are taught in the Lesson section. The lesson is presented by an anchorman. This part includes interactive animations and videos where the target forms and functions are used. The target forms and new vocabulary have been made salient by colours and they were reinforced by using videos. There are control buttons so that learners can control the anchorman's talk. Students can stop it at any time, control the volume, see the textual form of the anchorman talk, or they can watch the film starting from any point they like.

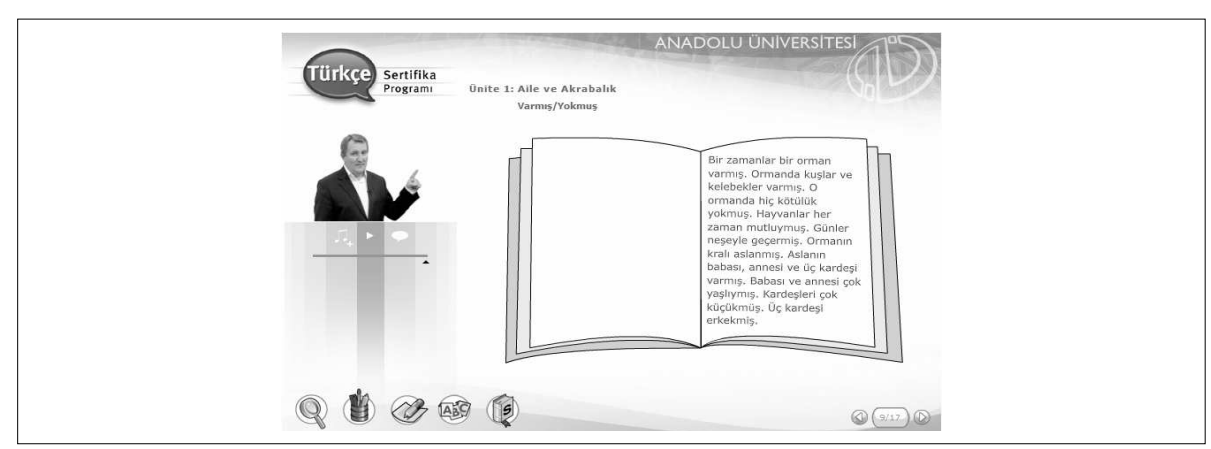

Figure 1. A sample lesson where the target forms have been made salient

Videos have three parts: serial film, cases, and music clips. Serial films have 12 episodes in each level. The serial films in each unit aim to help the acquisition of the target forms and functions. The cases include dramas regarding the skills taught in the lesson section. They show how the target forms are used in daily life. A short 
summary section exists at the end of the lesson section. At the end of each unit, students can access the test section including 20 multiple choice questions. In the Evaluation section, students can see their correct and wrong answers.

For new vocabulary and chunks, a Dictionary section has been designed. Each Turkish word has been vocalized. Translations of those words into English, French, or German are also available so that students can learn the meanings of the words. Each lesson includes a variety of activities such as multiple choice questions, matching exercises, choosing the right word or repetition drills. A virtual keyboard has been created so that students can use the letters that exist in Turkish such as 'ç, $\square, \breve{g}$, ö' etc. There is also an Alphabet section. In this section, students can hear the pronunciation of all the 29 letters in Turkish. As figure 2 indicates, the pictures of the words having concrete meanings initializing with the target letter is shown in this section.

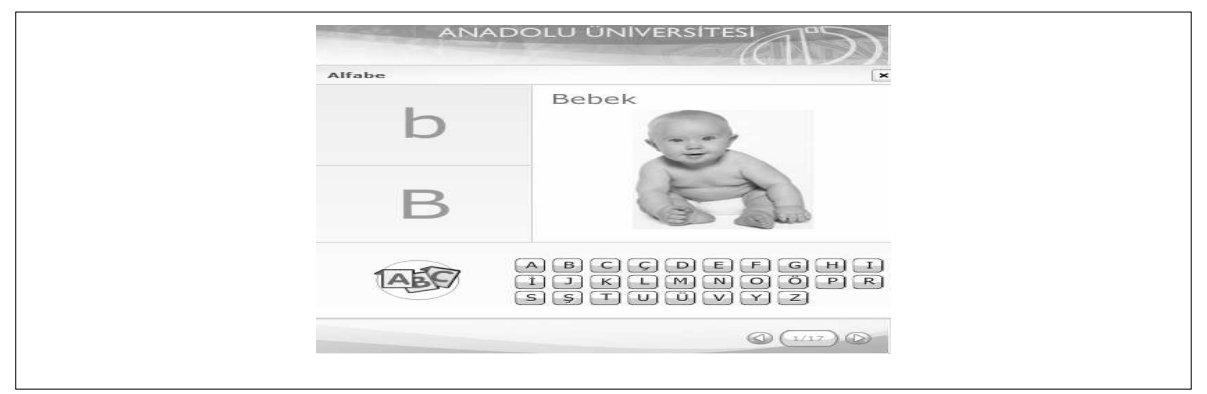

Figure 2. Sample page for learning Turkish alphabet

The rationale behind using pictures is the multimedia principle. The cognitive theory of multimedia learning states that learners need to build systematic connections between word-based representations and picture-based representations in order for meaningful learning to occur (Mayer, 2009) Using illustrations or animations in text helps students to better understand the presented explanation. In other words, presentation of an explanation with words and pictures leads to better learning than using words alone. When illustrations or animations are lacking, some learners can form their mental images based on the presented words, but use of pictures and animations causes a deeper learning, which is called generative processing.

At the end of each unit, there is a practice section. It includes many exercises about the target forms/functions. They are multiple choice, matching, fill in the blanks, and listening activities. Listening activities are based on repetition or choosing the correct answer while listening. Learning section includes many exercises about the target language taught in the unit. Printable course book, where the lesson content is offered in PDF format, is also available. Students who cannot have continuous Internet access can take print-outs and study wherever they want. 
Asynchronous \& Synchronous Facilitation Services are also offered to the students. The asynchronous facilitation service is offered by e-mail and discussion. Facilitators give the assignments every week and learners are required to send them via e-mail at a given date. In the assignments, learners are asked to do activities that allow them to reinforce what they have learned. As for synchronous facilitation service, 1 hour per day is offered. Ten students are assigned to one facilitator. Virtual classes have been created using Macromedia Breeze. Learners interact with their facilitators orally and in written form in the virtual classes and improve their speaking and writing skills.

There are many reasons for including synchronous facilitation service in the programme. The main reason is that use of synchronous facilitation service in the programme allows the process of scaffolding. Some researchers also state that synchronous electronic discourse is more efficient than ordinary classroom discourse because it allows the production of more complex language since there is less teacher domination compared to face-to-face classroom setting (Chun, 1994; Kern, 1995 cited in Sotillo, 2000). Similarly, Sotillo (2000) study showed that the quantity and types of discourse functions that were found in synchronous discussions were similar to the ones found in face-to-face interactions. There is evidence in the literature that CMC increases in the quantity of language output compared to face-to-face discussions and allows a more equal distribution of talk among participants. (LeLoup and Ponterio, 2003; Liu et al., 2003 cited in Kenning, 2007). It also gives learners more time to think and correct their errors, particularly in synchronous or asynchronous communication compared to unplanned spontaneous oral interaction. This may allow learners to gain more self confidence. Williams (2005) states that reduced time pressure to process messages during text-chat may allow learners the chance to notice a wider range of linguistic forms in the input than they might notice in real-time spoken input. In addition, planning time in text-chat may promote attention both to target language forms in the input and also to monitoring of target language output.

To see whether this distance language learning model works or not, students' examination results were obtained and an electronic interview was conducted. Some statistical data about the students in the programme can be found in the tables below.

Table 1 shows that among 165 students enrolled in the A1 level each term, 40 students i.e., nearly $25 \%$ of the students have successfully completed the A1 level.

Table 1. Number of Students Enrolled in and Successfully Completed the A1 level

\begin{tabular}{|l|c|c|}
\hline \multicolumn{1}{|c|}{ Terms } & $\begin{array}{c}\text { The Number of Students } \\
\text { In A1 Level }\end{array}$ & $\begin{array}{c}\text { The number of Students } \\
\text { Successfully Completed } \\
\text { A1 Level }\end{array}$ \\
\hline 2007 Fall & 42 & 8 \\
\hline 2008 Spring & 16 & 4 \\
\hline 2008 Summer & 5 & - \\
\hline 2008 Fall & 54 & 10 \\
\hline 2009 Spring & 39 & 16 \\
\hline 2009 Summer & 9 & 2 \\
\hline Total & $\mathbf{1 6 5}$ & $\mathbf{4 0}$ \\
\hline
\end{tabular}


Table 2 shows that among 83 students enrolled in the A2 level each term, 35 students i.e., $42 \%$ of the students have successfully completed the A2 level.

Table 2. Number of Students Enrolled in and Successfully Completed the A2 level

\begin{tabular}{|l|c|c|}
\hline \multicolumn{1}{|c|}{ Terms } & $\begin{array}{c}\text { The Number of Students } \\
\text { in A2 Level }\end{array}$ & $\begin{array}{c}\text { The number of Students } \\
\text { Successfully Completed } \\
\text { A2 Level }\end{array}$ \\
\hline 2008 Spring & 22 & 5 \\
\hline 2008 Summer & 7 & 4 \\
\hline 2008 Fall & 16 & 9 \\
\hline 2009 Spring & 26 & 13 \\
\hline 2009 Summer & 12 & 4 \\
\hline Total & $\mathbf{8 3}$ & $\mathbf{3 5}$ \\
\hline
\end{tabular}

As can be seen in Table 3, among 40 students enrolled in the B1 level each term, 17 students i.e., $43 \%$ of the students have successfully completed the B1 level. Those results show that the number of students who failed is higher in A1 level. The reason can be that those students are beginner level students and they find learning a new language difficult. Another reason may be that they are not experienced as distance language learners at the beginning. They may gain more experience as distance language learners and develop distance learning strategies as time goes on.

Table 3. Number of Students Enrolled in and Successfully Completed the B1 level

\begin{tabular}{|l|c|c|}
\hline \multicolumn{1}{|c|}{ Terms } & $\begin{array}{c}\text { The Number of Students } \\
\text { in B1 Level }\end{array}$ & $\begin{array}{c}\text { The number of Students } \\
\text { Successfully Completed } \\
\text { B1 Level }\end{array}$ \\
\hline 2008 Fall & 12 & 3 \\
\hline 2009 Spring & 14 & 7 \\
\hline 2009 Summer & 14 & 7 \\
\hline TOTAL & $\mathbf{4 0}$ & $\mathbf{1 7}$ \\
\hline
\end{tabular}

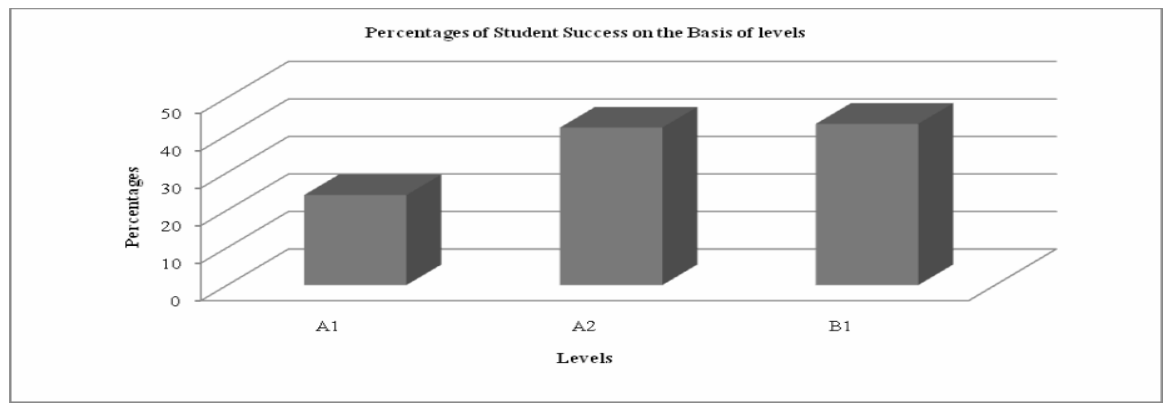

Figure 3. Percentages of Student Success In Terms of Levels 
As can be seen in Figure 4, the percentages of students passing to a higher level increase as students' proficiency level increases. The reason can be that students' Turkish language knowledge develops and also their awareness of the opportunities offered by the online programme increases.

As can be seen in the Table 4 and the Figure 5, rising from 42 to 82 , the number of students enrolled increased twice in the 2008 Fall term compared to the 2007 Fall term. The number of students which was 38 in the 2008 Spring term increased twice and rose to 79 in the 2009 Spring term. The number of students in the 2008 Summer term increased nearly three times and rose to 35 in the 2009 Summer period. This may be an indication that the students believe they can learn a language through distance education.

Table 4. The Number of Students Enrolled on the Basis of Terms

\begin{tabular}{|l|c|c|c|}
\hline \multicolumn{1}{|c|}{ Term } & $\begin{array}{c}\text { Total Number of } \\
\text { Students }\end{array}$ & Term & $\begin{array}{c}\text { Total Number of } \\
\text { Students }\end{array}$ \\
\hline 2007-Fall & 42 & $2008-$ Fall & 82 \\
\hline 2008- Spring & 38 & $2009-$ Spring & 79 \\
\hline 2008- Summer & 12 & $2009-$ Summer & 35 \\
\hline
\end{tabular}

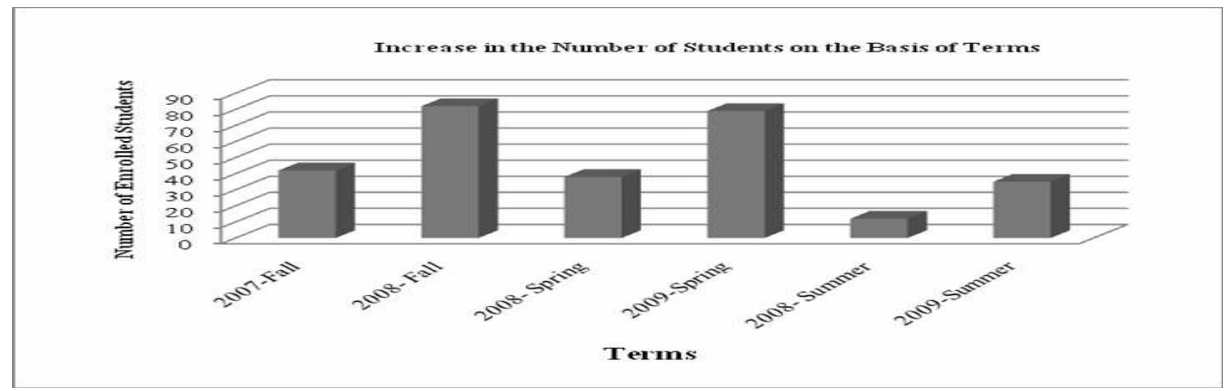

Figure 4. Increase in the Number of Enrolled Students on the Basis of Terms

An interview through electronic media was prepared by the researchers to understand the enrolled students' ideas on language learning through distance education and their comments about the programme. Views of two colleagues were taken into account while preparing the questions and some adjustments made on the initial questions. The questions were emailed at random to a group of learners. Only eight students answered the questions. The interview questions are as follows:

Q1. What are the things that you like in the Turkish Language Certificate Programme? 
Q2. What are the things that you do not like in the Turkish Language Certificate Programme?

Q3. Do you think distance education help foreign language learning? Why?

Q4. Do you think distance education hinder foreign language learning? Why?

Q5. What are your suggestions for the improvement of the Turkish Language Certificate Programme?

Q6. Which one leads to better learning do you think? Learning a foreign language in a face-to-face classroom or through distance education? Why?

Q7. Which one of the following is the easiest in distance education?

\begin{tabular}{|l|l|}
\hline a. learning grammar & b. learning vocabulary \\
\hline c. learning pronunciation & d. improving reading skills \\
\hline e. improving writing skills & f. improving speaking skills \\
\hline g. improving listening skills & \\
\hline
\end{tabular}

Q8. Which one of the following is the most difficult to learn through distance education?

\begin{tabular}{|l|l|}
\hline a. learning grammar & b. learning vocabulary \\
\hline c. learning pronunciation & d. improving reading skills \\
\hline e. improving writing skills & f. improving speaking skills \\
\hline g. improving listening skills & \\
\hline
\end{tabular}

The general findings of the interview are as follows:

For Q1, 'What are the things that you like in the Turkish Language Certificate Programme?' most students stated that they like learning aids such as videos, and music. They think that it is a nice atmosphere and a new style of learning. They are happy with learning in an interactive environment. They state that physical distance is dealt with thanks to distance learning. Some examples responses are as follows:

'Films are very useful to hear the language.'

'Very interactive, very positive to have webcam classes. It makes you learn a wide range of vocabulary. I have learned a lot of Turkish since I started.'

For Q2, 'What are the things that you do not like in the Turkish Language Certificate Programme?' students stated that the programme needs more exercises and the website is complex. They need explanations of grammar points in different languages. Technical problems such as Internet disconnection or problems in microphone cause to lose time. Students also need a summary of grammar points. 
'The website is quite complex to understand... but once you know where to find everything, it's $O K$.'

'Technical problems with connection'

For Q3, 'Do you think distance education help foreign language learning? Why?' most students replied 'Yes'. They think that they can work wherever and whenever they want thanks to distance learning.

'Yes, it helps, because you are saving the time (you don't have to spend time on the way to classes) and maybe your country does not offer language learning which you need. That's why it's great possibility.'

'Yes, because it is possible to decide for oneself, when to study.'

'I think it helps (of course depends on the persons wish to learn it), because it's comfortable to learn it even if you are not in the country, whose language you are trying to learn. You can study at the time that is suitable for you.'

For Q4, 'Do you think distance education hinder foreign language learning? Why?' although students state that it does not hinder foreign language learning, they still think that face-to-face learning is more efficient.

'Sometimes. It can never substitute real learning.'

'Sometimes yes. In my opinion the best way to learn foreign language is going to foreign country.'

'Rather no than yes. For sure in face-to-face classes you can gain more, but if you don't have that kind of options it helps a lot.'

For Q5, 'What are your suggestions for the improvement of the Turkish Language Certificate Programme?' students suggestions include more exercises, printable word lists, faster Internet connections and online live lessons.

'vocabulary exercises, in general more exercises online'

It seems not every student can use every service because of lack of appropriate technical equipment and for this reason they need alternatives. This supports Gillespie and McKee (1999) who found that learners resist using ICT in distance language learning because learners may have problems regarding equipment.

'printable lists of vocabulary to prepare before each lesson would be great. It may be existing in the online dictionary but as this online dictionary does not work with my equipment...'

For Q6, 'Which one leads to better learning do you think? Learning a foreign language in a face-to-face classroom or through distance education? Why?' all students stated that they prefer face to face learning. One of the students stated that face to face education is better than distance learning and distance education is better than working alone. The reasons for preferring face-to-face education are hearing teachers' pronunciation clearly, not facing with Internet connection problems, better concentration in face-to-face classrooms. 
'I think better is face-to-face learning because you have opportunity to hear your teacher clearly.'

'In a face-to-face class you can practice more pronunciation that is more important than grammar. I would prefer face-to-face classes.'

'Face-to-face is always better, but when it is not possible, distance learning is better than reading lessons on your own.'

'I didn't like that we didn't have face-to-face classes. Material was good, but it can be as additional aid to real lectures in class.'

For Q7, 'Which one of the following is the easiest in distance education?'

(Learning grammar, learning vocabulary, learning pronunciation etc.), the interview revealed that grammar is seen as the easiest topic to learn.

For Q8, 'Which one of the following is the most difficult to learn through distance education?' (learning grammar, learning vocabulary, learning pronunciation, etc.), most students stated that they found pronunciation most difficult to learn.

\section{Conclusion}

In this paper, Turkish Language Certificate programme offered by Anadolu University and what has been done in the programme to facilitate language learning for students were mentioned. When looking at the students' exam results, the number of successful students increases as students' proficiency level increases and it seems distance education certainly helps foreign language learning. The interview revealed that technical problems, lack of face-to-face interaction and difficulty of improving speaking skills are the major problems of distance language learning. From students' view, distance language learning is not as efficient as going abroad or as face-to-face language learning. Even though distance education helps students to learn a language, it is not what the students prefer if they have the chance to get face-to-face language instruction. Yet, distance language education is a good opportunity particularly for those who want to learn languages that are not taught in their country and for those who cannot go abroad for language learning.

If possible, distance language learning programmes should include more oral synchronous facilitation services or use videoconferencing to create more opportunities for oral interaction. More research should be carried out to identify and meet the needs of distance language learners and to follow their language development.

\section{References}

Chapelle C.A., Computer applications in second language acquisition: Foundations for teaching, testing and research, Cambridge, Cambridge University Press, 2001. 
Doughty C., "Second language instruction does make a difference: Evidence from an empirical study of SL relativization", Studies in Second Language Acquisition, vol. 13, 1991, p. 431-469.

Doughty C., "Computer applications in second language acquisition research: Design, description, and discovery", M. Pennington, V. Stevens (Eds.), Computers in applied linguistics: An international perspective, Clevedon, Avon: Multilingual Matters, Ltd., 1992, p. 127-154.

Gillespie J et McKee J., "Resistance to CALL: degrees of student reluctance to use CALL and ICT", ReCALL, vol. 11, n 1, 1999, p. 38-46.

Gitsaki C. et Taylor R., "Internet-based activities for the ESL classroom”, ReCALL, vol. 11, $\mathrm{n}^{\circ} 1,1999$, p. $47-57$.

Kenning M.M., ICT and Language Learning. From Print to the Mobile Phone, 2007.

Mayer R.E., Multimedia Learning, $2^{\text {nd }}$ ed., New York Cambridge University Press, 2009.

Sotillo S. M., "Discourse functions and syntactic complexity in synchronous and asynchronous communication", Language Learning and Technology, vol. 4, n 1, 2000, p. $82-119$.

Warschauer M., "Computer Assisted Language Learning: an Introduction”, Fotos S. (ed.) Multimedia language teaching, Tokyo: Logos International, 1996, p. 3-20.

Warschauer M., "Comparing face-to-face and electronic discussion in the second language classroom", CALICO Journal, vol. 13, n²-3, 1996, p.7-26.

Williams J., "Form-focused instruction", E. Hinkel (Ed.), Handbook of research in second language teaching and learning, Mahwah, NJ: Lawrence Erlbaum Associate, 2005, p. 671-691. 
